\title{
Effect of Different Nitrogen Levels and Plant Geometry on Yield and Nutrient Uptake by Brown Top Millet [Brachiaria ramosa (L.)]
}

\author{
Ashwani Kumar Thakur ${ }^{1 *}$, Prafull Kumar ${ }^{2}$ and Prahlad Singh Netam ${ }^{3}$ \\ ${ }^{1}$ Department of Agronomy, SG College of Agriculture and Research Station, Jagdalpur, India \\ ${ }^{2}$ Department of Genetics and Plant Breeding, SG College of Agriculture and Research \\ Station, Jagdalpur, India \\ ${ }^{3}$ Department of Plant Pathology, SG College of Agriculture and Research Station, \\ Jagdalpur, India \\ *Corresponding author
}

\begin{abstract}
A B S T R A C T
Keywords

Brown top millet,

Nitrogen level,

Geometry, Yield,

NPK content and

Uptake

Article Info

Accepted:

04 February 2019

Available Online:

10 March 2019

Experiment was conducted during Kharif season 2018 at New Upland Research Station cum Instructional Farm, Lamker under SG college of Agriculture and Research Station, Jagdalpur, Bastar (CG). The experiment was laid out in split plot design with three replications. Main plot was three levels of fertilizer i.e. $\mathrm{F}_{1}(75 \% \mathrm{RDF}), \mathrm{F}_{2}(100 \% \mathrm{RDF})$ and $F_{3}(125 \% \mathrm{RDF})$, and sub plot was four different spacing viz. $\mathrm{S}_{1}(22.5 \mathrm{x} 10 \mathrm{~cm}), \mathrm{S}_{2}(30$ x $10 \mathrm{~cm}), S_{3}(45 \times 10 \mathrm{~cm})$ and $S_{4}(60 \times 10 \mathrm{~cm})$. Grain yield, fodder yield per plot and per ha was recorded significantly highest in F3 among fertility levels. In case of different planting geometry, S4 recorded significantly higher grain yield but it was at par with S3 and S2. Fodder yield recorded significantly maximum in treatment S1 which was on par with S2 and S3. NPK content in grain and straw recorded significantly higher in treatment F3 (125\% RDF) but it was on par with F2 (100\% RDF) in N and P content in grain. In case of different planting geometry, $\mathrm{S} 4(60 \mathrm{x} 10 \mathrm{~cm})$ recorded statistically higher $\mathrm{P}$ content in straw which was at par with treatment S3.Treatment F3 recorded significantly higher NPK uptake in grain, straw and total uptake among fertility treatments but in case of different geometry, S4 recorded higher NK uptake in grain which was on par with S3 and S2.
\end{abstract}

\section{Introduction}

Brown top millet [Brachiaria ramosa (L.) Stapf; Panicum ramosum L.] is an introduced annual grass that originated in South-East Asia. It is grown in Africa, Arabia, China and Australia, Clayton et al., (2006). It was introduced to the United States from India in 1915 (Oelke et al., 1990). In the US, it is mainly grown in the South-East for hay, pasture and game bird feed. The browntop millet, called korale in Kannada, is specially grown in rainfed tracts of Tumakuru, Chitradurga and Chikkaballapura districts of Karnataka state. The crop is popular in this region in terms of cultivation and consumption. This millet seed is grown in a variety of soils and climates. Like other millets, it is a hardy crop and well suited for dry land (Bhat et al., 2018). Brown top millet is an annual warm-season species that grows 1 to $3 \mathrm{ft}$ tall. The smooth stems have pubescent nodes and may stand erect or 
ascend from a decumbent base. The leaves are 2.2 to $18 \mathrm{~cm}$ long and $6-18 \mathrm{~mm}$ wide; both surfaces are smooth. The inflorescence is indeterminate, open, spreading with simple axis and stalked flowers. It has 3-15 inflorescences and white flowers. Seeds are ellipsoid and tan in colour; they mature in approximately 60 days (Sheahan 2014). Brown top millet, which goes by the scientific name Brachiaria ramosa (L.) Stapf. or Urochloa ramosa (L.) R.D. Webster is known locally as pedda-sama and korne, and has a limited cultivation largely confined to southern India. Domestic and wild/weedy forms of brown top millet are found in agricultural systems, often within the same field. It is used as both a human food crop and fodder. Outside of India, it is grown in some parts of the USA as a fodder crop, largely to provide food for game birds, and was introduced from India around 1915. Although its distribution is highly relict today, restricted to parts remote parts of Andhra Pradesh, Karnataka, and Tamil Nadu states in southern India (Kimata et al., 2000), it appears to have been a major staple crop in the late prehistory of the wider region of the Deccan (Fuller et $a l .$, 2004). Panicle is distinct from Setaria by being looser and non-bristly, the grains themselves are very similar. Grains are ovate to round and have a long embryo, roughly two thirds to three fourths of the length of the grain. They tend to be smaller than Setaria italica and squatter in cross section. The surface of well-preserved grains can be used for identification as these have a distinctive undulating pattern, although this again has similarities to S. italica (Fuller et al., 2004). The husk has a fine beaded and rugose pattern, which again has some resemblance to that of Setaria spp., but it is somewhat coarser than $S$. italica and finer than. S. verticillata (https://www.researchgate.net/publication/286 351352). The productivity of brown top millet can be increased by applying of fertilizers. The presence of organic manure along with inorganic fertilizers helps in better availability of nutrients and moisture. Besides these, other advantages are reduction in seed rate, easy inter cultivation, better weed management and drip irrigation can also be adopted by providing wider spacing than the conventional method of planting (Prakasha et al., 2018). The present investigation was taken to develop a suitable nutrient management packages under upland condition. For that reason this research was undertaken to find out an optimum level of chemical fertilizer like urea and Di-Ammonium Phosphate (DAP) that can maximize growth characters, fodder and grain yield production of brown top millet under climatic and soil conditions of Bastar Plateau Zone of Chhattisgarh, India.

\section{Materials and Methods}

Experiment was conducted during Kharif season 2018 at New Upland Research Station cum Instructional Farm, Lamker under SG college of Agriculture and Research Station, Jagdalpur, Bastar, CG. The experiment was laid out in split plot design with three replications. Main plot was three levels of fertilizer ie. F1 (75\% RDF), F2 (100\% RDF) and F3 (125\% RDF), and sub plot was four different spacing viz. S1 $(22.5 \times 10 \mathrm{~cm}), \mathrm{S} 2$ $(30 \times 10 \mathrm{~cm}), \mathrm{S} 3(45 \times 10 \mathrm{~cm})$ and $\mathrm{S} 4(60 \times$ $10 \mathrm{~cm})$. Recommended dose of fertilizer was 40:20:00 $\mathrm{kg} \mathrm{N}: \mathrm{P}: \mathrm{K} \mathrm{kg} \mathrm{ha}^{-1}$. The soil was stony and calcareous in texture, low in organic carbon $(0.48 \%)$. available $\mathrm{N}(213.4$ $\left.\mathrm{kg} \mathrm{ha}^{-1}\right)$, available phosphorus (12.50 kg ha $\left.{ }^{-1}\right)$ and medium in available potassium $(228.6 \mathrm{~kg}$ ha-1) with soil reaction ( $\mathrm{pH}$ 5.5). Olsen's method (Watanabe and Olsen, 1965), Neutral normal Ammonium Acetate extract using flame photometer (Hanway and Heidel, 1952) and Walkely and Black method (Jackson, 1967) for the determination of available nitrogen $(\mathrm{N})$, phosphorus $\left(\mathrm{P}_{2} \mathrm{O}_{5}\right)$ potassium $\left(\mathrm{K}_{2} \mathrm{O}\right)$ and organic carbon, respectively. The $\mathrm{pH}$ of experimental site was determined 
through 1:2.5 soil and water suspension method (Jackson, 1967).Weather during kharif 2018 weekly pattern of different meteorological parameters are shown in figure 1 during kharif 2018. Total 1386.50 $\mathrm{mm}$ rainfall was recorded against the normal rain fall of $1414.92 \mathrm{~mm}$. Monsoon was active during $24^{\text {th }}$ SMW and received $26.04 \mathrm{~mm}$ water with two rainy days. Maximum rainfall was received during $29^{\text {th }}$ SMW $(130.7 \mathrm{~mm}$ with 4 rainy days), $32^{\text {th }}$ SMW (109.9mm with 5 rainy days), $33^{\text {th }}$ SMW $(152.7 \mathrm{~mm}$ with 5 rainy days) and $38^{\text {th }}$ SMW (175.7 mm with 6 rainy days). During cropping season maximum temperature was $34.5^{\circ} \mathrm{C}$ on $22^{\text {nd }}$ SMW and minimum temperature was recorded $20.40^{\circ} \mathrm{C}$ on $38^{\text {th }}$ SMW. The data obtained on various parameters were tabulated and subjected to statistical analysis. The difference of treatment was tested with $\mathrm{F}$ test, where $\mathrm{F}$ test shown their significance, the level of treatment were compared by critical difference at $5 \%$ level of probability. The skeleton of analysis of variance and formula used for various estimations are given by Gomez and Gomez (1984).

Data recorded on different parameters are presented in Table 1. Data revealed that grain yield, fodder yield per plot and per ha was recorded significantly highest in F3 (125\% RDF) among fertility levels. In case of different planting geometry, $S 4(60 \times 10 \mathrm{~cm})$ recorded significantly higher grain yield but it was at par with S3 $(45 \times 10 \mathrm{~cm})$ and S2 (30 x $10 \mathrm{~cm}$ ). Fodder yield recorded significantly maximum in treatment $\mathrm{S} 1(22.5 \times 10 \mathrm{~cm})$ which was on par with $\mathrm{S} 2(30 \times 10 \mathrm{~cm})$ and $\mathrm{S} 3(45 \times 10 \mathrm{~cm})$. The higher number of tillers at wider spacing intercepted more of solar radiation, water and increased nutrient availability helped to produce significantly higher number of tillers. Again less competition between plants due to wider space allowed the individual plants to develop massive root system. Better aeration at wider spacing resulted in healthy plant growth with higher yield (Prakasha et al., 2018). These results are in conformity with the findings of Narasimhamurthy and Hedge, (1981).

NPK content in grain and straw recorded in Table 2. The data shows that NPK content in grain and straw recorded significantly higher in treatment F3 (125\% RDF) but it was on par with F2 (100\% RDF) in N and P content in grain. In case of different planting geometry, S4 $(60 \times 10 \mathrm{~cm})$ recorded statistically higher $\mathrm{P}$ content in straw which was at par with treatment S3; remaining treatments were found no significant result Table 3. It might be due to more dry matter production by crop and less nutrient depletion due to better management practices and subsequently more availability of nutrients to crop. These findings corroborate with those of Mukherjee (2008) and Gupta et al., (2007).

NPK uptake in grain, straw and total NPK uptake by brown top millet was recorded in Table 2 and 3. The data reveals that treatment F3 (125\% RDF) recorded significantly higher NPK uptake in grain, straw and total uptake among fertility treatments but in case of different geometry, S4 $(60 \times 10 \mathrm{~cm})$ recorded higher NK uptake in grain which was on par with S3 $(45 \times 10 \mathrm{~cm})$ and $\mathrm{S} 2(30 \times 10 \mathrm{~cm})$. N and $\mathrm{K}$ uptake in straw was found higher in treatment $\mathrm{S} 1(22.5 \times 10 \mathrm{~cm})$ which was at par with $\mathrm{S} 2(30 \times 10 \mathrm{~cm})$ and $\mathrm{S} 3(45 \times 10 \mathrm{~cm})$, and $\mathrm{P}$ uptake in grain and straw, and total NPK uptake in plant was found no significant result during experimentation. Higher nutrient content in the produce and higher biomass production of finger millet might be the pertinent reason for higher uptake of nutrients. These results also reported by Mehta et al., (2005), Singh et al., (2011) and Sujatha et al., (2008). 
Table.1 Effect of different grain and straw yield of brown top millet

\begin{tabular}{|c|c|c|c|c|c|}
\hline Treatment & $\begin{array}{c}\text { Grain } \\
\text { weight plot }^{-1} \\
\text { (kg) }\end{array}$ & $\begin{array}{c}\text { Fodder yield } \\
\text { plot }^{-1}(\mathrm{~kg})\end{array}$ & $\begin{array}{l}\text { Test weight } \\
\text { (g) }\end{array}$ & $\begin{array}{l}\text { Grain Yield } \\
\quad\left(\mathbf{q} \mathbf{h a}^{-1}\right)\end{array}$ & $\begin{array}{c}\text { Straw yield } \\
\left(\mathbf{q} \mathbf{~ h a}^{-1}\right)\end{array}$ \\
\hline F1 & 1.63 & 3.53 & 2.88 & 7.10 & 15.58 \\
\hline F2 & 1.69 & 3.68 & 2.81 & 7.45 & 16.21 \\
\hline F3 & 1.76 & 4.16 & 2.97 & 8.17 & 18.32 \\
\hline SEm \pm & 0.02 & 0.01 & 0.09 & 0.10 & 0.44 \\
\hline CD at $5 \%$ & 0.10 & 0.40 & NS & 0.42 & 1.77 \\
\hline CV\% & 4.94 & 9.03 & 10.72 & 4.86 & 9.12 \\
\hline S1 & 1.58 & 4.43 & 2.70 & 6.97 & 19.53 \\
\hline S2 & 1.70 & 3.83 & 2.98 & 7.51 & 16.88 \\
\hline S3 & 1.73 & 3.77 & 3.00 & 7.61 & 16.64 \\
\hline S4 & 1.77 & 3.12 & 2.88 & 7.79 & 13.77 \\
\hline SEm \pm & 0.04 & 0.24 & 0.1 & 0.16 & 1.06 \\
\hline CD at $5 \%$ & 0.11 & 0.72 & $N S$ & 0.48 & 3.18 \\
\hline CV\% & 6.46 & 19.09 & 9.85 & 9.95 & 19.09 \\
\hline
\end{tabular}

$\mathrm{F}_{1}-75 \%$ RDF, $\mathrm{F}_{2}-100 \%$ RDF, $\mathrm{F}_{3}-125 \%$ RDF, $\mathrm{S}_{1}-22.5 \times 10 \mathrm{~cm}, \mathrm{~S}_{2}-30 \times 10, \mathrm{~S}_{3}-45 \times 10 \mathrm{~cm}$ and $\mathrm{S}_{4}-60 \times 10 \mathrm{~cm}$

Table. 2 NPK content and uptake by grain, straw in brown top millet

\begin{tabular}{|c|c|c|c|c|c|c|c|c|c|}
\hline \multirow[t]{2}{*}{ Treatment } & \multicolumn{3}{|c|}{ NPK content in grain $(\%)$} & \multicolumn{3}{|c|}{ NPK content in straw $(\%)$} & \multicolumn{3}{|c|}{ NPK uptake in grain $(\mathrm{kg})$} \\
\hline & $\mathrm{N}$ & $\mathrm{P}$ & $\mathrm{K}$ & $\mathrm{N}$ & $\mathrm{P}$ & $\mathrm{K}$ & $\mathrm{N}$ & $\mathrm{P}$ & $\mathrm{K}$ \\
\hline F1 & 1.53 & 0.203 & 0.418 & 0.322 & 0.204 & 0.679 & 11.02 & 3.017 & 4.98 \\
\hline F2 & 1.61 & 0.231 & 0.438 & 0.347 & 0.266 & 0.708 & 11.10 & 3.275 & 5.283 \\
\hline F3 & 1.63 & 0.247 & 0.485 & 0.384 & 0.298 & 0.738 & 12.67 & 3.773 & 5.729 \\
\hline$S E m \pm$ & 0.01 & 0.008 & 0.010 & 0.003 & 0.007 & 0.005 & 0.22 & 0.104 & 0.104 \\
\hline CD at $5 \%$ & 0.03 & 0.033 & 0.040 & 0.013 & 0.030 & 0.019 & 0.88 & 0.420 & 0.418 \\
\hline CV\% & 1.99 & 13.93 & 7.07 & & 6.249 & & 6.33 & 10.75 & 6.77 \\
\hline S1 & 1.57 & 0.224 & 0.440 & 0.336 & 0.241 & 0.692 & 10.95 & 3.077 & 4.840 \\
\hline S2 & 1.58 & 0.223 & 0.436 & 0.347 & 0.252 & 0.707 & 11.88 & 3.283 & 5.314 \\
\hline S3 & 1.61 & 0.227 & 0.454 & 0.357 & 0.260 & 0.712 & 12.26 & 3.467 & 5.429 \\
\hline S4 & 1.60 & 0.233 & 0.459 & 0.364 & 0.271 & 0.722 & 12.50 & 3.592 & 5.630 \\
\hline SEm \pm & 0.03 & 0.008 & 0.013 & 0.009 & 0.005 & 0.011 & 0.35 & 0.142 & 0.148 \\
\hline CD at $5 \%$ & $N S$ & $N S$ & $N S$ & $N S$ & 0.015 & $N S$ & 1.06 & $N S$ & 0.444 \\
\hline $\mathrm{CV} \%$ & 4.87 & 13.93 & 10.00 & & 1.976 & & 8.92 & 12.75 & 8.39 \\
\hline
\end{tabular}


Table.3 NPK uptake by grain, straw and total NPK uptake by plant (brown top millet)

\begin{tabular}{|c|c|c|c|c|c|c|}
\hline \multirow[t]{2}{*}{ Treatment } & \multicolumn{3}{|c|}{ NPK uptake in straw (kg) } & \multicolumn{3}{|c|}{ Total NPK uptake plant (kg) } \\
\hline & $\mathrm{N}$ & $\mathrm{P}$ & $\mathrm{K}$ & $\mathrm{N}$ & $\mathrm{P}$ & $\mathrm{K}$ \\
\hline F1 & 4.982 & 3.154 & 10.563 & 16.00 & 6.17 & 15.46 \\
\hline F2 & 5.613 & 4.293 & 11.461 & 17.59 & 7.57 & 16.75 \\
\hline F3 & 6.980 & 5.468 & 13.476 & 19.68 & 9.24 & 19.20 \\
\hline SEm \pm & 0.191 & 0.187 & 0.246 & 0.23 & 0.16 & 0.221 \\
\hline CD at $5 \%$ & 0.768 & 0.756 & 0.993 & 0.94 & 0.66 & 0.89 \\
\hline $\mathrm{CV} \%$ & 11.27 & 13.81 & 7.21 & 4.56 & 7.43 & 4.46 \\
\hline S1 & 6.569 & 4.752 & 13.516 & 17.51 & 7.83 & 18.36 \\
\hline S2 & 5.859 & 4.321 & 11.981 & 17.74 & 7.60 & 17.30 \\
\hline S3 & 5.987 & 4.422 & 11.919 & 18.25 & 7.89 & 17.35 \\
\hline S4 & 5.019 & 3.723 & 9.918 & 17.52 & 7.31 & 15.54 \\
\hline SEm \pm & 0.401 & 0.317 & 0.782 & 0.42 & 0.27 & 0.77 \\
\hline CD at 5\% & 0.768 & NS & 2.341 & $N S$ & NS & $N S$ \\
\hline $\mathrm{CV} \%$ & 20.55 & 20.22 & 19.82 & 7.01 & 10.72 & 13.52 \\
\hline
\end{tabular}

Fig.1 Weekly weather data 2018

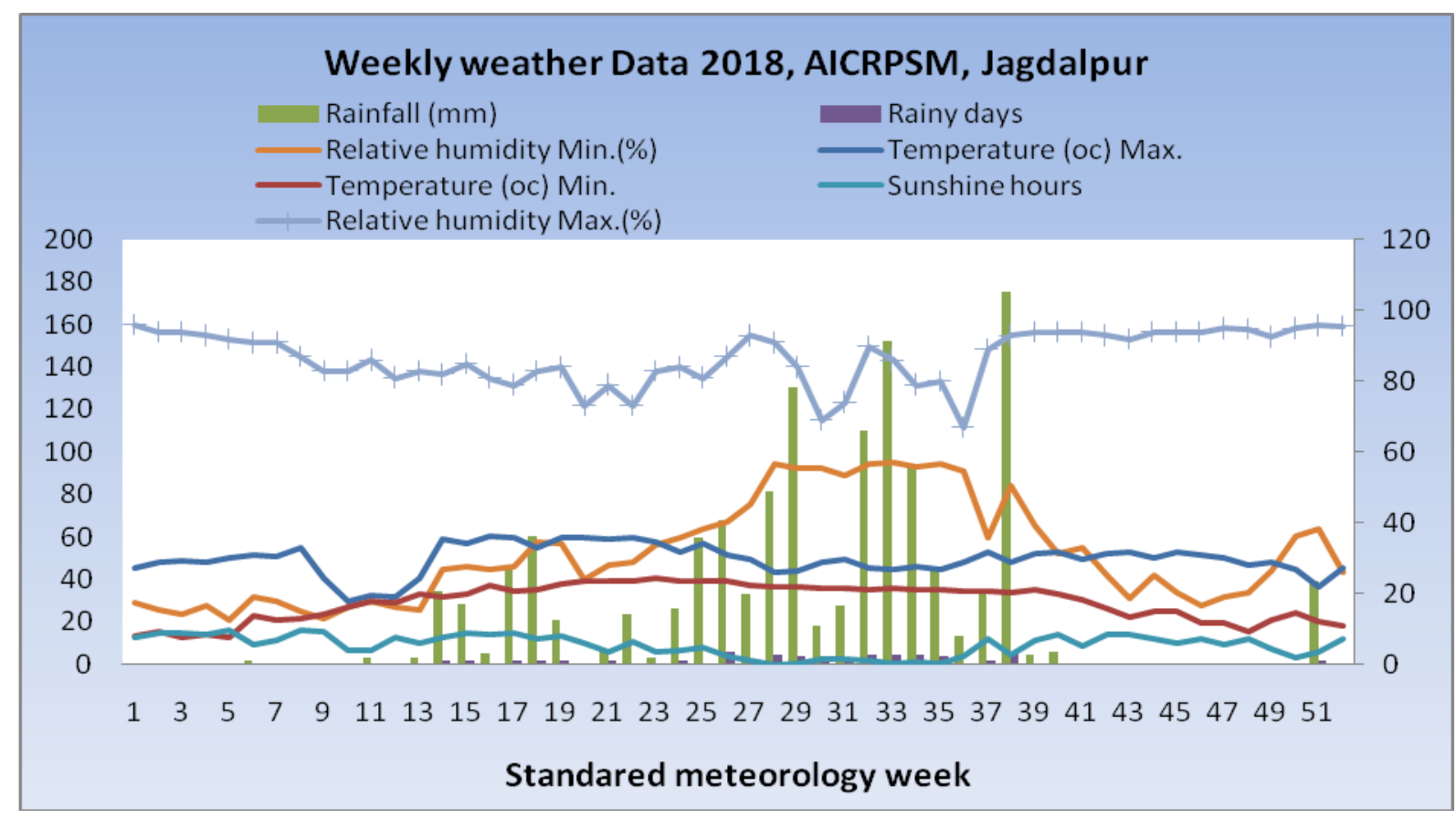

\section{Acknowledgement}

The authors are thankful to Project Coordinator, All India Coordinated Research Project on Small Millets (AICRPSM),
Bangalore, Karnataka and Dean SG College of Agriculture and Research Station, Jagdalpur, Chhattisgarh for providing grants and physical support for conducting the experiment. 


\section{References}

Bhat, S., Ganiger Prabhu C., Nandini, C., Prabhakar and Thippeswamy, V. 2018. Browntop

Millet- A Review Agri Res \& Tech: Open Access J., 14(5): 001-002.

Clayton,W.D., Vorontsova, M.S., Harman, K.T. and Williamson, H. 2006 Grass Base-the online world grass flora.

Fuller, D.Q., Korisettar, R., Venkatasubbaiah, P.C. and Jones, M. K. 2004. Early plant domestications in southern India: some preliminary archaeobotanical results. Vegetation History and Archaeobotany, 13: 115-29.

Gomez, K.A. and Gomez, A.A. 1984. Statistical procedures for agricultural research. A Willey- Inter Sci. Publication. John Willey \& Sons, New York.

Gupta, M., Bali, A. S, Sharma, B. C., Kachroo, D. and Bharat, R. (2007). Productivity, nutrient uptake and economics of wheat under various tillage and fertilizer management practices. Indian Journal of Agronomy, 52: 127-130.

Hanumantharao, Y., Bapireddy, Y., Yellamanda Reddy, T. and Shankara Reddy, G. H., 1982. Effect of different levels of nitrogen, phosphorus and potassium on the growth and yield of finger millet. Andhra Agril. J., 29(1): $37-41$.

Hanway, J. J. and Heidel, H. 1952. Soil analysis, as used in Iowa State. College of Soil Testing Laboratory, Iowa, Agriculture, 57: 1-31.

https://www.researchgate.net/publication/286 351352.

Jackson, M. L. 1967. Soil chemical analysis, Prentice Hall of Inc. New York, US.A.

Kimata, M., Ashok, E.G. and Seetharam, A. 2000. Domestication, cultivation and utilization of two small millets,
Brachiaria ramosa and Setaria glauca (Poaceae) in South India. Economic Botany, 54 (2): 217-27.

Mehta, Y. K., Shaktawat, M. S. and Singh, S. M. 2005. Influenced of sulfer, phosphorus and FYM on yield attributes and yield of maize (Zea mays) in south Rajasthan conditions. Ind. J. Agron. 50(3): 203-205.

Mukherjee, D. (2008). Effect of tillage practices and fertility levels on the performance of Wheat (Triticum aestivum) under mid hill condition of West Bengal. Indian Journal of Agricultural Sciences, 78(12): 103841.

Narasimhamurthy and Hegde, B. R., 1981, Tillering in relation to intra-row competition in ragi under rainfed conditions. Indian J. Agron., 26(3): 337-338.

Oelke, E. A, Oplinger, E.S., Putnam, D.H., Durgan, B.R. and Doll, J.D.1990. Millets. In: Alternative Field Crops Manual. Univ of Wisc-Ext Serv, Univ of Minn ExtServ and Univ. of Minn. CAPAP.

Prakasha, G., Kalyana Murthyl, K.N., Prathima, A.S. and Meti, Rohani N.2008. Effect of Spacing and Nutrient Levels on Growth Attributes and Yield of Finger Millet (Eleusine coracana L. Gaertn) Cultivated under Guni Planting Method in Red Sandy Loamy Soil of Karnataka, India. Int.J.Curr.Microbiol.App.Sci (2018) 7(5): 1337-1343.

Sheahan, C. M. 2014. Plant guide for browntop millet (Urochloa ramosa). USDA-Natural Resources Conservation Service, Cape May Plant Materials Center, Cape May.

Singh, G. Sharma, G. L. and Golada, S. L. 2011. Effect of enriched FYM with fertilizers \& biofertilizers on yield, harvest index, protein, nitrogen and 
phosphorous content in grains. J. of Progressive Agriculture., 2(3): 65-67.

Sujatha, Lingaraju, M.G., Y. B. Palled and Ashalatha, K. V. 2008. Importance of integrated nutrient management practices in maize under rainfed condition, Karnataka J. of Agri. Sci.,
21(3): 334-338.

Watanabe, F. S. and Olsen, S. R. 1965. Test of an ascorbic acid method for determining phosphorus in water and NaHCO3 extracts. Soil Sci. Soc. Amr. Proc., 29: 677-678.

\section{How to cite this article:}

Ashwani Kumar Thakur, Prafull Kumar and Prahlad Singh Netam. 2019. Effect of Different Nitrogen Levels and Plant Geometry on Yield and Nutrient Uptake by Brown Top Millet [Brachiaria ramosa (L.)]. Int.J.Curr.Microbiol.App.Sci. 8(03): 223-229. doi: https://doi.org/10.20546/ijcmas.2019.803.029 